\title{
Effects of rumen fill on short-term ingestive behavior and circulating concentrations of ghrelin, insulin, and glucose of dairy cows foraging vegetative micro-swards
}

\author{
P. Gregorini, ${ }^{* 1,2}$ K. J. Soder, ${ }^{*}$ and R. S. Kensingert ${ }^{3}$ \\ *USDA-ARS Pasture Systems and Watershed Management Research Unit, Bldg. 3702, University Park, PA 16802 \\ †Department of Dairy and Animal Science, The Pennsylvania State University, 324 Henning Bldg, University Park 16802
}

\begin{abstract}
The objective of this study was to investigate changes in foraging behavior, hunger-related hormones, and metabolites of dairy cows in response to short-term variations in rumen fill (RF). The effect of $\mathrm{RF}$ on intake rate, jaw movements, bite rate and dimensions, and concentrations of plasma ghrelin, and serum insulin and glucose were measured in 4 rumen-cannulated lactating dairy cows ( $612 \pm 68 \mathrm{~kg}$, empty live weight; $237 \pm 29 \mathrm{~d}$ in milk) foraging micro-swards of vegetative orchardgrass (Dactylis glomerata L.). The treatments compared were the removal of different proportions of total rumen contents: 1.00 (RF0), 0.66 (RF33), 0.33 (RF66), or 0 (RF100). Treatments were randomly applied $2 \mathrm{~h}$ before foraging sessions in a $4 \times 4$ Latin square design. Micro-swards were weighed before and after foraging sessions. Cows were allowed to take a maximum of 15 bites with no time restriction. Eating time, intake rate, total jaw movements, and bite mass, depth, area, and rate were determined. Plasma was analyzed for ghrelin and serum for insulin and glucose immediately before and $2 \mathrm{~h}$ after the treatments were applied. Intake rate, bite mass, and bite area increased, whereas bite depth decreased as RF decreased. The RF did not affect bite rate or total jaw movements. Decreasing RF resulted in increased plasma concentrations of ghrelin and tended to increase serum insulin, with reduced concentrations of serum glucose. Incremental variation in plasma ghrelin and serum insulin correlated with bite depth and mass, whereas changes in serum glucose correlated with intake rate, bite area, depth and mass, as well as with herbage intake per jaw movement. The present study elucidates some of the underlying endocrine physiology
\end{abstract}

\footnotetext{
Received October 12, 2008.

Accepted January 2, 2009.

${ }^{1}$ Corresponding author: Pablo.Gregorini@dairynz.co.nz

${ }^{2}$ Present address: DairyNZ, Private Bag 3221, Hamilton, New Zealand.

${ }^{3}$ Present address: Department of Animal Science, Oklahoma State University, Stillwater.
}

of cattle with short-term temporal variations of $\mathrm{RF}$ and their effects on some components of foraging behavior. Key words: dairy cow, rumen fill, foraging behavior, appetite-regulating hormone

\section{INTRODUCTION}

The grazing process has been described as a series of complex interactions, including ingestive and digestive behaviors (Alden and Whittaker, 1970) and hormonal and metabolic constraints to food intake (Illius and Jessop, 1996; Forbes, 2003). However, most advances in the appreciation of the plant-animal interface have come from research determining how canopy structure influences the rate of herbage intake (Laca et al., 2001). Although recent research has focused on short-term internal factors influencing foraging behavior, few integrative studies have been undertaken.

Hunger motivates animals to eat. Rumen fill (RF) is inversely related to hunger (Newman et al., 1994; Chilibroste et al., 1997), with level of hunger influencing herbage intake rate and grazing dynamics (Thomson et al., 1985; Gregorini et al., 2007a). As RF increases during the progression of a grazing bout, beef heifers decreased intake rate, increased searching time, and decreased bite mass, but maintained a constant bite rate (Gregorini et al., 2007a). These results are consistent with those of Chilibroste et al. (1997) who reported that grazing dairy cows decreased herbage intake rate when artificial fillers were introduced into their rumens. This phenomenon may be related to satiety factors (Campling and Balch, 1961; Ivlev, 1961) and feeding behavior stimuli/motivation at a discrete meal level and has been extensively studied in humans, rats, and swine (Day et al., 1997, 1998).

Ghrelin, a 27-AA peptide, has recently been suggested as a powerful, peripherally active, orexigenic agent (Wren et al., 2000; Kobelt et al., 2006; Roche et al., 2007). Plasma ghrelin concentration increases in response to fasting and decreases during subsequent feeding in humans (Cummings et al., 2001) and ruminants 
(Hayashida et al., 2001; Wertz-Lutz et al., 2006; Roche et al., 2007). The orexigenic property of ghrelin may be involved in determining feeding mechanisms and behavior (Nakazato et al., 2001; Sugino et al., 2004) as well as energy balance (Hosada et al., 2002), the latter being related to glucose and insulin metabolism (Mendez et al., 2006; Takahashi et al., 2006). The positive relationship between plasma ghrelin concentrations and DMI has been demonstrated in confined sheep (Mendez et al., 2006). However, there is still a lack of information associating changes in concentrations of ghrelin with changes in components of foraging behavior. Little is known regarding how foraging ruminants adjust bite dimensions and instantaneous herbage intake rate according to different hunger levels, or if short-term temporal variations in $\mathrm{RF}$ (as occurring in a grazing bout; Taweel et al., 2005; Gregorini et al., 2008) reflect changes in metabolic hormones and metabolites. The objective of this study was to determine the effect of $\mathrm{RF}$ on short-term foraging behavioral tactics, including bite dimensions and instantaneous herbage intake rate, and on the concentration of plasma ghrelin and serum insulin and glucose, in cattle grazing vegetative temperate grass presented as micro-swards.

\section{MATERIALS AND METHODS}

This study was approved by the Institutional Animal Care and Use Committee of The Pennsylvania State University (Protocol \# 25768).

\section{Site, Rumen Fill Treatments, and Experimental Design}

The study was conducted at the USDA-ARS Pasture Systems and Watershed Management Research Unit and The Pennsylvania State University Dairy Research and Education Center (University Park, PA) during September 2007. The $4 \mathrm{RF}$ treatments comparing the removal of different proportions of total rumen contents: 1.00 (RF0), 0.66 (RF33), 0.33 (RF66), or 0 (RF100) were randomly applied in a $4 \times 4$ Latin square design (Kuehl, 1999) using 4 lactating Holstein cows over 4 consecutive 1-d experimental periods.

\section{Animals, Feeding, and Rumen Fill Treatment Set-Up}

Four rumen-cannulated lactating Holstein cows (612 $\pm 68 \mathrm{~kg}$, empty BW; $237 \pm 29 \mathrm{DIM}$ ) were placed in a tie-stall barn 2 wk before the beginning of the experiment. One week before the experimental period, cows were adapted to the micro-swards, solid-state behavior recorders (Rutter et al., 1997), and to experimental activities such as rumen evacuations. During the adap- tation and experimental periods, cows were fed a TMR (CP, 164 g/kg; ADF, 220 g/kg; NDF, 340 g/kg; starch, $210 \mathrm{~g} / \mathrm{kg}$; and total digestible nutrients, $710 \mathrm{~g} / \mathrm{kg}$ of DM) to meet NRC (2001) recommendations for maintenance and milk production. Cows were offered $20 \%$ of total daily allowance at $0800 \mathrm{~h}$ (after morning milking). At $1200 \mathrm{~h}$, refusals were weighed and recorded, and cows were fasted for $2 \mathrm{~h}$ before the foraging sessions of approximately $30 \mathrm{~min}$, after which the remaining daily feed allowance (fed ad libitum for $10 \%$ refusal) was offered, approximately $6.5 \mathrm{~h}$ after the morning feed.

The RF treatments were set following a similar protocol outlined by Gregorini et al. (2007a). Beginning at $1200 \mathrm{~h}$, rumens were sequentially (30 min apart) emptied and total rumen contents weighed, which was $4 \mathrm{~h}$ after the morning meal (which was also sequentially fed) and $2 \mathrm{~h}$ before the foraging session (approximately $1400 \mathrm{~h}$ ). The RF treatments were based on rumen content mass $4 \mathrm{~h}$ after the morning meal. Solid rumen contents were removed by hand and placed in 190-L plastic containers. Liquid rumen contents were removed with a plastic beaker and placed in the same containers. Total rumen contents (solid and liquid) were weighed, thoroughly mixed, and returned to the rumen according to level of RF treatment. After each foraging session, rumen contents not used for RF treatment set-up were returned to the rumen. During each rumen evacuation a representative sample of $1,000 \mathrm{~g}$ (wet weight) of rumen contents was collected from each cow and separately analyzed for DM (oven-dried at $60^{\circ} \mathrm{C}$ for $48 \mathrm{~h}$ ).

\section{Micro Sward Set-Up and Management}

In January 2007, 20 monoculture micro-swards of orchardgrass (Dactylis glomerata L.) were established in plastic boxes (16 experimental and 4 control boxes, 79 $\mathrm{cm} \times 47 \mathrm{~cm} \times 11.5 \mathrm{~cm}$, weighing $4.5 \mathrm{~kg}$ when empty) as described by Orr et al. (2005). All boxes had 28 drainage holes $(0.6 \mathrm{~cm})$ spaced at $10 \mathrm{~cm}$. Each box was filled with a potting soil containing 55 to $65 \%$ medium grade horticultural vermiculite and 35 to $45 \%$ Choice Plug grade Canadian Sphagnum Peat Moss (Scott's Miracle-Gro Products Inc., Marysville, OH). Seeding rate $\left(500\right.$ seeds $\left./ \mathrm{m}^{2}\right)$ was based on the previously tested germination rate. To control environmental changes during establishment, micro-swards were kept in a temperature-controlled greenhouse (rerandomized 4 times to remove greenhouse location effect). Micro-swards were watered regularly to maintain field capacity moisture for optimal growth. Once the micro-swards were well established in terms of height and tillering, they were sequentially cut (in groups of 5 boxes, 1 group a day) using handheld electric clippers to $6 \mathrm{~cm}$ above the root/shoot interface using a graduated vertical marker 
guide. This sequence was repeated approximately every $21 \mathrm{~d}$ when canopies had approximately 4 fully expanded leaves per tiller, but before the oldest tiller leaf blades senesced. All micro-swards were fertilized after each cut with $\mathrm{N}, \mathrm{P}$, and $\mathrm{K}$ at $17.9,35.8$, and $17.9 \mathrm{~kg} / \mathrm{ha}$, respectively. After the third cut, all micro-swards were placed outdoors until the foraging sessions.

Micro-sward boxes to be used that day were transported to the experimental site $(2 \mathrm{~km}$ from the greenhouse area) approximately $1 \mathrm{~h}$ before the initiation of the testing periods. At the end of each testing period (approximately $5 \mathrm{~h}$ later), boxes were returned to the greenhouse sites.

\section{Measurements}

Sward Canopy and Herbage Characterization. Before the beginning of each daily foraging session, the undisturbed sward surface height (SSH) of each of the 4 experimental micro-swards and 1 control micro-sward was determined using a sward height stick (Bircham, 1981). Data were collected at 10 fixed points in each micro-sward. Total DM herbage mass was determined from the control micro-sward by hand clipping herbage at root/shoot level from 2 randomly placed $15 \times 15 \mathrm{~cm}$ quadrats. Chemical composition of herbage was determined by canopy stratum $(5 \mathrm{~cm}$, from the top to the bottom from 2 randomly placed $15 \times 15 \mathrm{~cm}$ quadrats) in the control micro-sward. Samples were pooled by canopy stratum and frozen at $-20^{\circ} \mathrm{C}$, freeze-dried, and analyzed for level of DM, CP, NDF, ADF, starch, and total digestible nutrients (Dairy One Forage Laboratory, Ithaca, NY). Ten randomly selected tillers were collected from the control micro-swards for toughness measurement and estimation of module of elasticity (indirect approximation of the elastic resistance to break [gradient/cross-sectional area]; G. Ziegler, The Pennsylvania State University, University Park; personal communication). Tillers were collected at the time of the foraging session $(1400 \mathrm{~h})$ and immediately placed on ice in a cooler. Approximately $30 \mathrm{~min}$ after collection, the second fully extended leaf of each tiller was clipped and cut crosswise into 5 portions $5 \mathrm{~cm}$ in length to match the canopy strata analyzed for chemical composition. Each leaf portion (from tip to ligule) was set in a TA-XT2i texture analyzer (Texture Technologies Corp., Scarsdale, NY) and tested for compression force (fracture; Wright and Illius, 1995). Stable Micro Systems (Windows-compatible specialist) and Texture Expert Exceed software (Stable Micro Systems Ltd., Texture Technologies Corp.) was utilized to calculate the total work force $(\mathrm{N} \cdot \mathrm{mm})$ and module of elasticity $(\mathrm{N} / \mathrm{mm})$. These 2 parameters were multiplied by the cross-sectional area (lamina width $\times$ thickness) at the breaking point for toughness measurement (Wright and Illius, 1995) and module of elasticity estimation.

Ingestive Behavior Measurements and Calculations. Foraging session and behavior measurements were collected during 4 consecutive days (1 period per day). Each day, cows (with corresponding $\mathrm{RF}$ treatment) were presented with 1 micro-sward test box. All test micro-swards were weighed immediately before and after the foraging session to an accuracy of $\pm 0.1 \mathrm{~g}$ (IS1501GG-S0CE, Sartorius AG, Gottingen, Germany). The control micro-sward was also weighed directly before and after each foraging session to correct for evapotranspiration losses $(0.07 \mathrm{~g} / \mathrm{s})$. The length of each foraging session was not time restricted (17.3 $\pm 5 \mathrm{~s}$ ) but the number of bites was controlled. Cows were permitted to take a maximum of 15 bites from the micro-sward to minimize bite overlapping effect (Benvenutti et al., 2006), as overlapping reduces bite area (Ungar and Noy-Meir, 2001). The bite number was based on the average number of bites per feeding station as reported by Wade et al. (2006), and bite area was estimated as described previously (Gregorini et al., 2006, 2007a).

Ingestive behavior while foraging was recorded with solid-state behavior recorders (Rutter et al., 1997) and a digital video camera (Sony Handycam, DCRDVD408, Sony Corporation, Tokyo, Japan). Behavior recorders were placed on each cow immediately before the foraging session. The video camera was set at 1.5 $\mathrm{m}$ from each foraging scenario (cow and micro-sward) to avoid disturbing the foraging session. Data provided by behavior recorders were analyzed using the Graze software (Rutter, 2000). Total jaw movements and number of bites were determined. Video recordings were used to confirm the number of bites. Foraging time was measured using a stopwatch, and eating time was determined from video recordings.

Herbage DM mass consumed was calculated by the corrected weight change of the micro-sward and the DM concentration of the herbage. Herbage intake rate was determined by dividing the herbage DM mass consumed by eating time. Bite mass was calculated by dividing the amount of herbage DM consumed by the number of bites taken $(\mathrm{n}=15)$. Bite rate was calculated by dividing the number of bites by eating time. Bite depth was measured by the difference in surface height as described by Gregorini et al. (2007a). Ten measurements of surface height of the herbage were taken within the micro-sward in areas grazed and a further 10 undisturbed surface heights of herbage were taken immediately adjacent to the grazed area. Bite area was estimated using the model of Laca and Ungar (1992) based on bite depth, bite mass, and grazed stratum bulk density. Grazed stratum bulk density was 
calculated based on apparent bite depth and the average biomass of 2 samples cut from the grazed stratum (samples cut at estimated bite depth within one $15 \times$ $15 \mathrm{~cm}$ quadrat placed in ungrazed areas adjacent to a bitten area). These samples were analyzed for leaf:stem ratio. The remaining herbage in the ungrazed area was hand clipped at ground level and the leaf:stem ratio calculated.

Blood Collection and Hormone and Glucose Analysis. Blood samples were collected sequentially (relative to feeding to match RF treatments) from the coccygeal vein 3 times daily for 4 consecutive days; before (to detect differences in hunger level at the beginning of each day; $0800 \mathrm{~h}$, bleed 1) and after the morning meal (1200 h; bleed 2), and immediately before the foraging session (1400 h; bleed 3). Blood was collected into one 10-mL evacuated blood tube (anticoagulant-free) and $10-\mathrm{mL}$ evacuated blood tubes containing $18 \mathrm{mg}$ of $\mathrm{K}_{2}$ EDTA. The latter were immediately treated with a protease inhibitor $(10 \mu \mathrm{L}$ of phenylmethylsulfonyl fluoride), and all samples were placed on ice in a cooler, and centrifuged at $3,000 \times g$ for $15 \mathrm{~min}$ at $4^{\circ} \mathrm{C}$. Plasma and serum were frozen at $-20^{\circ} \mathrm{C}$ until analysis.

Plasma active (acetylated) ghrelin concentrations were determined using a commercially available RIA (multispecies ghrelin active kit, Linco Research Inc. St. Charles, MO; Roche et al., 2007). This assay utilizes ${ }^{125}$ I-labeled ghrelin and a ghrelin antiserum to determine plasma concentration of ghrelin by the double antibody-polyethylene glycol technique. As mentioned by Roche et al. (2007), this assay is specific for the first 11 AA of ghrelin and the octanoyl moiety, being previously validated for bovine plasma by Wertz-Lutz et al. (2006). The lowest level of ghrelin that can be detected by this assay is $7.8 \mathrm{pg} / \mathrm{mL}$ when using a $100-\mu \mathrm{L}$ sample size. Inter- and intraassay coefficients of variation were $<15$ and $10 \%$, respectively. Serum insulin concentrations were determined using a commercially available RIA (porcine insulin kit, Linco Research Inc.). This assay utilizes ${ }^{125}$ I-labeled insulin and a porcine insulin antiserum to determine the serum concentration of insulin by the double antibody-polyethylene glycol technique. This assay is $90 \%$ specific for bovine insulin. Inter- and intraassay coefficients of variation were $<15$ and $10 \%$, respectively. The lowest level of insulin that can be detected by this assay is $2 \mu \mathrm{U}$ when using a 100$\mu \mathrm{L}$ sample size. Plasma glucose concentrations were determined using a commercially available kit (Glucose procedure no. 1075, Stanbio Laboratory, Boerne, TX). This assay quantitatively determines glucose concentrations by enzymatic colorimetric procedures. The Stanbio single-reagent glucose method is based on a technique described by Trinder (1959). Inter- and in- traassay coefficients of variation for all the assays were $<10$ and $5 \%$, respectively.

\section{Statistical Analysis}

The effect of RF on dependent variables (ingestive behavior, plasma ghrelin, serum insulin, and serum glucose concentrations at bleed 3 and the difference between bleeds 3 and 2) was analyzed by ANOVA as a $4 \times 4$ Latin square using linear models (PROC GLM, SAS Inst. Inc., Cary, NC). The model included fixed effects for cow, period, and RF treatment. The linear and quadratic effects of RF were detected using orthogonal contrasts with a protected $F$-test. To characterize the relationship between dependent variables, Pearson correlations were performed using PROC CORR (SAS Inst. Inc.). Hormone and glucose concentrations before the RF treatments were applied (bleeds 1 and 2) were analyzed by ANOVA using the GLM procedure of SAS. The terms in the statistical model included the fixed effects of time (before and after morning meal), period and the interaction period $\times$ time. Least squares means were compared using the PDIFF function of SAS. In all statistical analyses, a value of $P<0.01$ was considered significant.

\section{RESULTS}

\section{Herbage Features in the Micro-Swards}

The SSH of the micro-swards was $22.7 \pm 3 \mathrm{~cm}$. Herbage mass was $230 \pm 36 \mathrm{~g}$ of $\mathrm{DM} / \mathrm{m}^{2}(21.3 \pm 4 \% \mathrm{DM})$. Herbage mass distribution from the top to the bottom of the canopy (5-cm layers) was 1.5, 6.1, 14.0, 30.6, and $47.8 \%$ of the total herbage mass, respectively. Chemical and biomechanical features of herbage are presented in Table 1.

\section{Behavioral Measurements}

Fresh rumen contents $(15 \pm 1 \% \mathrm{DM})$ for RF0, RF33, RF66, and RF100 averaged 0, 54, 106, and $161 \mathrm{~g} / \mathrm{kg}$ of $\mathrm{BW}(\mathrm{SEM}=0.016 \mathrm{~g})$, respectively.

Eating was defined as head down and entirely involved in severing bites. During all foraging sessions, all cows were completely involved in eating activity. Therefore, the herbage intake rates ( $g$ of DM per unit of time) were not different from either foraging or eating time (Table 2). Herbage intake rate decreased linearly $(P=0.006)$. Rumen fill did not affect $(P=0.491)$ bite rate. Bite mass decreased linearly $(P<0.001)$ with increasing RF, whereas bite depth increased linearly $(P$ $<0.001)$. Bite area decreased linearly $(P=0.001)$ as 
Table 1. Chemical composition (\% of DM) and biomechanical properties of micro-sward herbage at different canopy strata

\begin{tabular}{|c|c|c|c|c|c|}
\hline \multirow[b]{2}{*}{ Item } & \multicolumn{5}{|c|}{ Canopy stratum $^{1}(5 \mathrm{~cm})$} \\
\hline & 1 & 2 & 3 & 4 & 5 \\
\hline $\mathrm{DM}$ (\% fresh) & 25 & 25 & 21.5 & 19.3 & 15.7 \\
\hline $\mathrm{CP}$ & 16 & 16 & 21.5 & 20.2 & 14.5 \\
\hline $\mathrm{ADF}$ & 27.2 & 27.2 & 27.1 & 29.7 & 38.9 \\
\hline NDF & 57.2 & 57.2 & 53.5 & 58.2 & 68.3 \\
\hline Starch & 4.2 & 4.2 & 2.4 & 1.8 & 1.6 \\
\hline Total digestible nutrients & 66 & 66 & 63 & 65 & 53 \\
\hline Toughness $^{2}\left(\mathrm{~N} / \mathrm{mm}^{2}\right)$ & 0.57 & 0.71 & 1.06 & 1.33 & 1.26 \\
\hline Module of elasticity ${ }^{2}(\mathrm{~N} / \mathrm{mm})$ & 0.34 & 0.32 & 0.26 & 0.25 & 0.23 \\
\hline
\end{tabular}

${ }^{1}$ Canopy stratum from the top (1) to the bottom (5) of the canopy.

${ }^{2}$ From the tip to the ligule of the second fully expanded leaf.

RF increased. Although no effect $(P=0.303)$ of $\mathrm{RF}$ on total jaw movements per bite was evident, the amount of herbage harvested per jaw movement linearly decreased $(P=0.006)$ with increasing RF. The leaf:stem ratio of the grazed residual canopy stratum decreased linearly $(P<0.001)$ with increasing RF.

\section{Ghrelin, Insulin, and Glucose Concentrations}

The concentrations of insulin and glucose in serum did not differ in bleed $1(P=0.42)$ and bleed $2(P=$ 0.682 ), before and after the morning meal, respectively. Mean values for insulin concentration across all RF treatments were 16.3 and $19.9 \mu \mathrm{U} / \mathrm{mL}$ (SEM 1.73) for bleed 1 and bleed 2, respectively. Mean glucose plasma concentrations across all RF treatments were 71.3 and $71.1 \mathrm{mg} / \mathrm{dL}$ (SEM 1.34) for bleed 1 and bleed 2, respectively. Mean plasma ghrelin concentration across did not differ in bleed 1 (123.1 SEM 7.18; $P=0.07$ ) or bleed 2 (77.9 SEM 5.84; $P=0.597$ ).

Plasma ghrelin concentrations at bleed 3 decreased linearly $(P=0.001)$ as $\mathrm{RF}$ increased. The difference in plasma ghrelin concentration between bleed 3 (at foraging time) and bleed 2 decreased linearly $(P=$ 0.001) as RF increased (Table 3). Rumen fill did not affect concentrations of insulin $(P=0.374)$ or glucose $(P=0.252)$ at the time of foraging (bleed 3; Table 3$)$. The difference in plasma insulin concentration between bleed 3 and bleed 2 was not affected $(P=0.073)$ by RF . The difference in serum glucose concentration between bleed 3 and bleed 2 decreased linearly $(P<0.001)$ as $\mathrm{RF}$ increased.

\section{Correlations Between Plasma Ghrelin, Serum Insulin and Glucose, and Ingestive Behavior Variables}

Pearson correlation coefficients among the dependent variables are presented in Table 4 . The difference in plasma ghrelin concentration between bleed 3 and bleed 2 was positively $(P=0.003)$ and negatively ( $P$ $<0.001$ ) associated with bite mass and depth, respectively. The difference in serum insulin concentration between bleed 3 and bleed 2 correlated negatively $(P<$ $0.001)$ with bite depth. The difference in serum glucose concentration between bleed 3 and bleed 2 correlated positively with intake rate $(P=0.006)$ and bite area $(P$

Table 2. Effect of rumen fill on foraging behavior (least squares means) of Holstein dairy cows grazing an artificial vegetative temperate sward

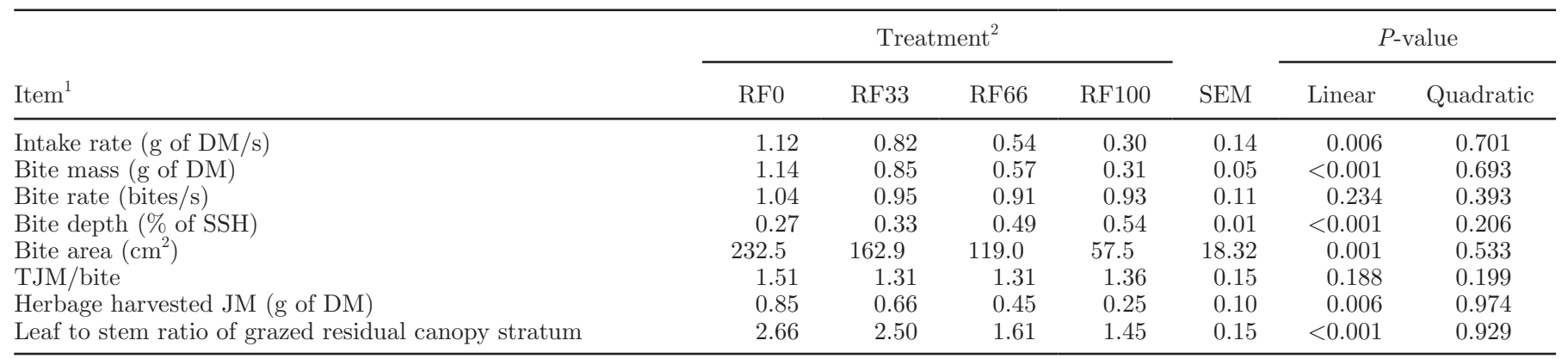

${ }^{1} \mathrm{SSH}=$ undisturbed sward surface height; TJM = total jaw movements related to bites (no chews were detected); JM = jaw movements. ${ }^{2} \mathrm{RF} 0=$ removal of all rumen contents; RF33 = removal of 0.66 of total rumen contents; RF66 = removal of 0.33 of total rumen contents; RF100 $=$ no removal of rumen contents. 
Table 3. Effect of rumen fill on plasma ghrelin and serum insulin and glucose concentrations (least squares means) of Holstein dairy cows grazing an artificial vegetative temperate sward

\begin{tabular}{|c|c|c|c|c|c|c|c|}
\hline \multirow[b]{2}{*}{ Item $^{1}$} & \multicolumn{4}{|c|}{ Treatment $^{2}$} & \multirow[b]{2}{*}{ SEM } & \multicolumn{2}{|c|}{$P$-value } \\
\hline & RF0 & RF33 & RF66 & RF100 & & Linear & Quadratic \\
\hline \multicolumn{8}{|l|}{ Ghrelin } \\
\hline Bleed $3(\mu \mathrm{g} / \mathrm{dL})$ & 286.7 & 310.9 & 149.4 & 98.8 & 23.12 & 0.001 & 0.087 \\
\hline Bleed 3 - bleed $2(\mu \mathrm{g} / \mathrm{dL})$ & 178.7 & 228.5 & 57.8 & 9.5 & 23.48 & 0.001 & 0.082 \\
\hline \multicolumn{8}{|l|}{ Insulin } \\
\hline Bleed $3(\mu \mathrm{U} / \mathrm{mL})$ & 16.1 & 8.13 & 11.8 & 8.5 & 2.31 & 0.283 & 0.423 \\
\hline Bleed 3 (mg/dL) & 63.7 & 64.5 & 65.9 & 71.2 & 2.51 & 0.077 & 0.422 \\
\hline Bleed 3 - bleed $2(\mathrm{mg} / \mathrm{dL})$ & -9.9 & -6.3 & -2.4 & -0.3 & 0.79 & $<0.001$ & 0.339 \\
\hline
\end{tabular}

${ }^{1}$ Bleed 3 = at foraging time; bleed $2=2 \mathrm{~h}$ before bleed 3 (at the time treatments were set).

${ }^{2} \mathrm{RF} 0=$ removal of all rumen contents; RF33 = removal of 0.66 of total rumen contents; RF66 = removal of 0.33 of total rumen contents; RF100 $=$ no removal of rumen contents.

$=0.003)$ and tended to be positively associated with herbage harvested per jaw movement $(P=0.01)$. Such a difference correlates negatively $(P<0.001)$ with bite depth.

\section{DISCUSSION}

\section{Herbage Characteristics of the Micro-Swards}

The level of herbage mass $(2,300 \pm 36 \mathrm{~kg}$ of DM/ha), SSH $(22 \pm 2 \mathrm{~cm})$, and the vegetative character of the micro-sward herbage indicate that herbage consumption would not have been constrained by availability or accessibility of herbage in these simulated feeding stations. Mass (DM) distribution, chemical composition, and biomechanical features of herbage down the canopy strata indicate that cows faced different nutrient rewards and harvesting and processing features according to bite depth.

Toughness describes the resistance of a material to the spread of a crack (Atkins and Mai, 1985) and can be related to the energy applied (shear force) to grass when being chewed (Wright and Illius, 1995). Chewing (ingestion or rumination) of herbage is energetically more costly (on average by a factor of 3 ) than harvesting the herbage (Wright and Illius, 1995). Toughness and harvesting effort (tensile strength) are positively correlated to decreasing ratios of nonstructural to structural carbohydrates (Wright and Illius, 1995; Perez-Barbería and Gordon, 1998), as well as to reductions in forage DM (less brittle; Vickers, 1977; Vincent, 1983; Galli et al., 2006). From the toughness data presented in Table 1 , it can be inferred that the cows faced a heterogeneous canopy in the vertical dimension. Although module of elasticity cannot be utilized to quantify harvesting effort directly, the vertical heterogeneity in mass and chemical composition as well as the increasing DM percentage from ligule to tip and an increase in the cross-sectional area (width $\times$ thickness, from the ligulae to the tip of the leaf) of the canopy indirectly indicate no change or even reductions in the harvesting effort from the top to the bottom canopy stratum.

\section{Herbage Intake Rate and Foraging Behavior}

The transmission of signals to the brain in response to amounts of digesta in the rumen is considered to be an important determinant of forage intake regulation (Weston, 1996). Consequently, it was hypothesized that within the same feeding environment, the varying intensity of these signals would result in different intake rates. This premise was demonstrated by Gregorini et al. (2007a) and is supported by the results of the present study. Gregorini et al. (2007a) reported similar decreases in herbage intake rate at both patch and feeding station level as RF increased in beef heifers grazing Bermudagrass (Cynodon dactylon L. Pers) using RF treatments analogous to those in the present study. These results are consistent with earlier research that reported decreased herbage DM intake rates when $\mathrm{RF}$ was simulated by placing plastic bags in the rumens of grazing dairy cows (Chilibroste et al., 1997). Based on the natural progressive increase in RF as ruminants graze (Thiago, 1988), the results of the present study (particularly from RF33 to RF66) simulated the dynamic decrease of intake rate during a grazing bout and emphasized the importance of physical control in the dynamics of herbage intake at a grazing bout level as suggested by Gregorini et al. (2007a).

In addition to $\mathrm{RF}$, the rate at which a grazing ruminant ingests herbage (bite mass $\times$ bite rate) depends on herbage availability, accessibility, and quality (Ungar and Noy-Meir, 2001). Bite rate depends upon the searching time and the time required for the prehension 
Table 4. Correlations ${ }^{1}$ among ingestive behavior, ghrelin, insulin, and glucose variables of Holstein dairy cows grazing an artificial vegetative temperate sward with 4 levels of rumen fill ${ }^{2}$

\begin{tabular}{|c|c|c|c|c|c|c|c|c|c|c|c|c|}
\hline Item $^{3,4}$ & BA & $\mathrm{BD}$ & BM & $\mathrm{BR}$ & TJM/bite & HI/JM & $\begin{array}{l}\text { Ghrelin: } \\
\text { bleed } 3\end{array}$ & $\begin{array}{c}\text { Ghrelin: } \\
\text { bleed } 3 \text { - } \\
\text { bleed } 2\end{array}$ & $\begin{array}{l}\text { Insulin: } \\
\text { bleed } 3\end{array}$ & $\begin{array}{l}\text { Insulin: } \\
\text { bleed } 3- \\
\text { bleed } 2\end{array}$ & $\begin{array}{l}\text { Glucose: } \\
\text { bleed } 3\end{array}$ & $\begin{array}{c}\text { Glucose: } \\
\text { bleed } 3- \\
\text { bleed } 2\end{array}$ \\
\hline \multirow{2}{*}{ IR } & 0.96 & -0.69 & 0.92 & 0.67 & -0.37 & 0.98 & 0.35 & 0.36 & -0.50 & 0.35 & -0.60 & 0.64 \\
\hline & $<0.001$ & 0.002 & $<0.001$ & 0.004 & 0.151 & $<0.001$ & 0.181 & 0.177 & 0.046 & 0.180 & 0.012 & 0.006 \\
\hline \multirow{2}{*}{ BA } & & -0.71 & 0.96 & 0.67 & -0.26 & 0.96 & 0.40 & 0.40 & -0.47 & 0.40 & -0.56 & 0.68 \\
\hline & & 0.001 & $<0.001$ & 0.013 & 0.330 & $<0.001$ & 0.122 & 0.138 & 0.065 & 0.115 & 0.021 & 0.003 \\
\hline \multirow{2}{*}{ BD } & & & -0.75 & -0.25 & -0.12 & -0.67 & -0.79 & -0.71 & 0.43 & -0.74 & 0.21 & -0.86 \\
\hline & & & $<0.001$ & 0.343 & 0.646 & 0.004 & $<0.001$ & $<0.001$ & 0.091 & $<0.001$ & 0.416 & $<0.001$ \\
\hline \multirow{2}{*}{$\mathrm{BM}$} & & & & 0.49 & -0.15 & 0.94 & 0.54 & 0.54 & -0.42 & 0.49 & -0.58 & 0.71 \\
\hline & & & & 0.056 & 0.565 & $<0.001$ & 0.003 & 0.003 & 0.101 & 0.048 & 0.018 & 0.001 \\
\hline \multirow{2}{*}{$\mathrm{BR}$} & & & & & -0.73 & 0.64 & -0.15 & 0.03 & -0.54 & 0.08 & -0.67 & 0.28 \\
\hline & & & & & 0.001 & 0.007 & 0.576 & 0.912 & 0.029 & 0.762 & 0.003 & 0.293 \\
\hline \multirow{2}{*}{ TJM/bite } & & & & & & -0.40 & 0.31 & 0.19 & 0.35 & 0.29 & 0.41 & 0.24 \\
\hline & & & & & & 0.119 & 0.293 & 0.494 & 0.181 & 0.200 & 0.109 & 0.365 \\
\hline \multirow{2}{*}{ HI/JM } & & & & & & & 0.37 & 0.38 & -0.49 & 0.35 & -0.60 & 0.60 \\
\hline & & & & & & & 0.156 & 0.158 & 0.053 & 0.181 & 0.012 & 0.012 \\
\hline \multirow{2}{*}{ Ghrelin: bleed 3} & & & & & & & & 0.97 & -0.13 & 0.54 & -0.10 & 0.60 \\
\hline & & & & & & & & $<0.001$ & 0.632 & 0.027 & 0.698 & 0.015 \\
\hline \multirow{2}{*}{ Ghrelin: bleed 3 - bleed 2} & & & & & & & & & -0.16 & 0.46 & -0.23 & 0.54 \\
\hline & & & & & & & & & 0.543 & 0.081 & 0.376 & 0.033 \\
\hline \multirow{2}{*}{ Insulin: bleed 3} & & & & & & & & & & -0.19 & 0.33 & -0.31 \\
\hline & & & & & & & & & & 0.402 & $\begin{array}{r}0.208 \\
-0.04\end{array}$ & 0.234 \\
\hline Insulin: bleed 3 - bleed 2 & & & & & & & & & & & 0.878 & $<0.001$ \\
\hline Glucose: bleed 3 & & & & & & & & & & & & $\begin{array}{l}-0.35 \\
0.172\end{array}$ \\
\hline
\end{tabular}

${ }^{1}$ Upper values indicate Pearson correlation values; lower values are $P$-values.

${ }^{2} \mathrm{RF} 0=$ removal of all rumen contents; RF33 = removal of 0.66 of total rumen contents; RF66 = removal of 0.33 of total rumen contents; RF100 = no removal of rumen contents.

${ }^{3} \mathrm{IR}=$ intake rate; $\mathrm{BA}=$ bite area; $\mathrm{BD}=$ bite depth; $\mathrm{BM}=$ bite mass; $\mathrm{BR}=$ bite rate; TJM = total jaw movements; $\mathrm{HI} / \mathrm{JM}=$ herbage intake per jaw movement.

( ${ }^{4}$ Bleed $3=$ at foraging time; bleed $2=2 \mathrm{~h}$ before bleed 3 (at the time treatments were set). 
and processing of a bite (Hobbs et al., 2003), which can be affected by SSH (Burlison and Illius, 1991; Gibb et al., 1997) and bulk density (Ungar 1996; Casey et al., 2004). The cows in the current study were presented with designed uniform micro-swards to control much of the natural horizontal variation commonly associated with field pastures. With sward variables minimized, the pattern of bite rate and bite mass found in the present study related directly to level of RF. Hunger has been reported to increase bite rate (Dougherty et al., 1989; Patterson et al., 1998; Gregorini et al., 2007b). However, this was not the case in the present study or in field work with grazing cattle (Chilibroste et al., 1997; Gregorini et al., 2007a), where there was no evident effect of $\mathrm{RF}$ on bite rate.

The homogeneous unrestricted foraging scenarios of the present experiment, the lack of difference in total jaw movement per unit of time, and the absence of searching time (foraging time minus eating time) may explain the lack of difference in bite rate, and emphasize the importance of bite mass and bite dimensions (bite depth and area) in determining intake rate under these conditions. As RF decreased, bite mass increased indicating an effect of hunger on the dimensions of each bite, but not the jaw movements per bite and rate of prehension.

In the present study, bite depth decreased and bite area increased with decreasing RF. These effects are consistent with results with beef heifers on a Bermudagrass sward (Gregorini et al., 2007a). Bite depth has been hypothesized (Hodgson et al., 1994; Griffiths and Gordon, 2003) to be an active mechanism of selection for leaf in the vertical dimension of a sward canopy. Bite depth appears to be influenced by harvesting effort, directly relating to the increment of toughness and tensile strength from the top to the bottom of the sward canopy (Griffiths and Gordon, 2003). However, the vertical variations in biomechanical features of the canopy strata in this experiment were the same for all $\mathrm{RF}$ treatments. Consequently, results indicate that control of bite dimensions is dynamically integrated with information received on the hunger status of the animal; in this case, rumen epithelial stretch receptors. There are several reports of constancy of proportion between bite depth and SSH independently of the leaf layer depth (Wade et al., 1989; Wade, 1991; Flores et al., 1993). Therefore, bite depth may be a passive response to active bite area regulation (Wade and Carvalho, 2000), responding to hunger and interacting with canopy structure. The greater proportion of stem in the grazed residual canopy stratum and the greater magnitude of change in bite area compared with bite depth as RF decreased (Table 2), as well as the stronger correlation
(Table 4) between bite area and mass than between bite depth and mass, would support this premise.

The results of this experiment and those reported by Gregorini et al. (2007a) indicate that cattle respond to an energy acquisition stimulus by changing bite dimensions (mainly bite area) instead of increasing bite rate. This is consistent with the results of Di Marco et al. (1996), who found that bite rate, at different levels of pasture availability, was positively associated with energy expenditure in grazing beef cattle. Energy expenditure was estimated at $16.6 \mathrm{KJ} / \mathrm{h}$ at a bite rate of $28 \mathrm{bites} / \mathrm{min}$ and $22.6 \mathrm{KJ} / \mathrm{h}$ at a bite rate of 59 bites/ min for high and low pasture availability, respectively (Di Marco et al., 1996). The short-term profitability of different plants as prey of herbivores has been defined by Fortin (2001) as a function of digestible energy per unit of handling time. According to the chemical composition and the biomechanical features (Table 1), bite mass, bite dimensions (depth and area), and mass of herbage consumed per total jaw movement in the present study (Table 2), the profitability of bites markedly differed and was dependent upon RF. As RF decreased, more-profitable bites were taken. Therefore, cattle dynamically alter foraging behavior to increase energy intake at minimal energy cost with decreasing $\mathrm{RF}$. This phenomenon is supported by the consistent increment in stem proportion in the grazed residual canopy stratum as RF increased.

\section{Plasma Ghrelin, Serum Insulin, and Serum Glucose as Affected by Rumen Fill and its Relation with Foraging Behavior}

Previous experiments have clearly demonstrated the positive relationship between ghrelin concentration and DMI of sheep (Miura et al., 2004; Mendez et al., 2006), dairy cows (Roche et al., 2007), and beef steers (WertzLutz et al., 2006). Additionally, ghrelin has been reported to interact with energy metabolism parameters such as insulin and glucose concentrations (Itoh et al., 2006; Wertz-Lutz et al., 2006; Roche et al., 2008). Despite the importance of the effect of ghrelin on feed intake regulation, to our knowledge there are no reports on the effect of ghrelin on specific foraging mechanisms. Rumen fill naturally increases over the day and within grazing bouts (Thiago, 1988) and this has been related to grazing bout-ingestive behavior (Thomson et al., 1985; Gregorini et al., 2007a). In cattle, ghrelin is synthesized primarily in the abomasum, but also in rumen tissues (Hayashida et al., 2001; Gentry et al., 2003) and responds to feeding schedules, especially in mature cattle with a completely developed rumen (Miura et al., 2004). Sugino et al. (2003) and Wertz-Lutz et al. (2008) 
considered rumen distension to be an explanation for changes in circulating ghrelin concentrations and the duration of such changes. The results from the present study are consistent with this hypothesis.

The RF generated in the present experiment may simulate the RF dynamics during the progression of a grazing bout (Gregorini et al., 2007a), especially in the treatments RF33, RF66, and RF100. Nakazato et al. (2001) and Sugino et al. (2004) suggested that the orexigenic property of ghrelin may be involved in determining feeding mechanisms and behavior. The results of the present study do not support a direct relation between herbage intake rate and ghrelin concentrations (Table 4). However, when treatment RF0 was not taken into account in the Pearson correlation analysis, ghrelin concentration variables tended to correlate with herbage intake rate (Pearson coefficients $=0.54$ and 0.53 , $P=0.061$ and $P=0.092$ for ghrelin concentration at bleed 3 and bleed 3 minus bleed 2, respectively). These results cannot support a direct response in ingestion rate to ghrelin concentrations. Ghrelin concentrations, however, correlate negatively with bite depth and positively with bite mass (Table 4 ), demonstrating the potential effect of circulating levels of ghrelin on foraging mechanisms and suggesting an indirect relation with intake rate.

Ghrelin has been linked to energy balance (Hayashida et al., 2001; Hosada et al., 2002) through insulin and glucose metabolism (Itoh et al., 2006; Takahashi et al., 2006; Roche et al., 2008). For example, Patel et al. (2006) showed a direct effect of ghrelin on glucose uptake by adipose tissue, and Wertz-Lutz et al. (2006) and Roche et al. (2008) reported a rapidly decline in plasma ghrelin concentration in steers and cows, respectively, after a glucose infusion. In the present study, the decline of glucose and increase of ghrelin, as RF decreased, are in agreement with the aforementioned studies. Insulin acts as both a short- and long-term regulator of feed intake (Woods et al., 1979). The results of the present experiment add to this effect, directly or indirectly relating the physical stimuli coming from the rumen to the role of this hormone in intake regulation. Pearson correlation analysis indicated that insulin concentration (bleed 3 minus bleed 2) correlated with bite depth and tended to be associated with bite mass (Table 4). Increments of insulin stimulate intake by lowering the circulating level of energy supply; for example, glucose (Grovum, 1995). In the present study, serum insulin and glucose concentrations (bleed 3 minus bleed 2) were strongly correlated, which matches the lower concentrations of serum glucose as RF decreased and the prior theory (Grovum, 1995). In fact, serum glucose concentrations (Table 4) showed the highest Pearson coefficient values when correlated to foraging behavior variables.
Ghrelin may convey peripheral nutritional status to the central nervous system and communicate the need for nutrient intake (i.e., due to depletion in energy supply as glucose suppressed by insulin) or decreased energy expenditure (Gil-Campos et al., 2006; WertzLutz et al., 2008). Previous work (Tang-Christensen et al., 2004; Mendez et al., 2006) suggested that a secondary role of ghrelin is the reduction of overall locomotor activity as a mechanism to decrease energy expenditure. Decreasing RF in the present study generated increasing concentrations of ghrelin. As RF decreases, step rate during eating, as well as searching and eating distance, is reduced (Gregorini et al., 2007a). These considerations, the foraging behavior results, and the descriptive features (nutritive value and biomechanical features) of the canopy strata of the present experiment may lead to assumptions and speculations about the relationship between foraging tactics and changes in metabolic hormones and metabolites. In doing that, caution is suggested to readers at the time of drawing conclusions.

\section{CONCLUSIONS}

Little was known regarding bite dimensions and instantaneous herbage intake rate adjustment as a function of RF or if short-term temporal variations of $\mathrm{RF}$ reflect changes in the underlying endocrine physiology. This study showed that lactating dairy cows may adjust bite mass through specific ingestive behavior such as increasing bite area as a mechanism to increase instantaneous acquisition of energy in response to decreasing levels of "physical stimulation" signals coming from the rumen. These signals seem to be mediated by insulin-glucose metabolism and potentially conveyed by ghrelin. The present study elucidates some of the underlying endocrine physiology of cattle through short-term temporal variations of $\mathrm{RF}$ and their effect upon foraging behavior.

\section{ACKNOWLEDGMENTS}

We thank Melissa Rubano (USDA-ARS, University Park, PA), Ann Magliaro (Penn State University, University Park, PA), and Felipe Montes (USDA-ARS, University Park, PA) for their invaluable help during the sample collection period and analysis, as well as Gregory Ziegler (Penn State University) for his help in the utilization of the Texture Analyzer and data interpretation. The authors also acknowledge John R. Roche (Dairy NZ), Michael H. Wade (Universidad Nacional del Centro de la Provincia de Buenos Aires, Tandil, Argentina), Dave Clark (Dairy NZ), Rene Flores (University of Arkansas, Little Rock), Paul A. Beck 
(University of Arkansas, Fayetteville), and Stacey A. Gunter (USDA-ARS, Woodward, OK) for their critical review, ideas, and comments on the manuscript.

\section{REFERENCES}

Alden, W. G., and I. A. Whittaker. 1970. The determinants of herbage intake by grazing sheep: The interrelationship of factors influencing herbage intake and availability. Aust. J. Agric. Res. 21:755-766.

Atkins, A. G., and Y. W. Mai. 1985. Elastic and Plastic Fracture. Ellis Horwood Ltd., West Sussex, UK.

Benvenutti, M. A., I. J. Gordon, and D. P. Poppi. 2006. The effect of the density and physical properties of grass stems on the foraging behaviour and instantaneous intake rate by cattle grazing and artificial reproductive tropical sward. Grass Forage Sci. 61:272281.

Bircham, J. S. 1981. Herbage growth and utilization under continuous stocking management. PhD Thesis. University of Edinburgh, Edinburgh, UK.

Burlinson, A. J. H., and A. W. Illius. 1991. Sward canopy structure and the bite dimensions and bite weight of grazing sheep. Grass Forage Sci. 46:29-38.

Campling, R. C., and C. C. Balch. 1961. Factors affecting the voluntary intake of foods by cows. I. Preliminary observations on the effect, on voluntary intake of hay, of changes in the amount of the reticulo-rumen contents. Br. J. Nutr. 15:523-531.

Casey, I. A., A. S. Laidlaw, A. J. Brereton, D. A. McGilloway, and S. Watson. 2004. The effect of bulk density on bite dimensions of cattle grazing microswards in the field. J. Agric. Sci. 142:109121.

Chilibroste, P., S. Tamminga, and H. Boer. 1997. Effects of length of grazing session, rumen fill and starvation time before grazing on dry matter intake, ingestive behavior and dry matter rumen pool sizes of grazing lactating dairy cows. Grass Forage Sci. 52:249257.

Cummings, D. E., J. Q. Purnell, R. S. Frayo, K. Schmidova, B. E Wisse, and D. S. Weeigle. 2001. A preprandial rise in plasma ghrelin levels suggests a role in meal initiation in humans. Diabetes 50:1714-1719

Day, J. E., I. Kyriazakis, and P. Rogers. 1998. Food choice and intake: A unifying framework of learning and feeding motivation. Nutr. Res. Rev. 11:25-43.

Day, J. E., I. Kyriazakis, and P. Rogers. 1997. Feeding motivation in animals and man: A comparative review of its measurements and uses. Nutr. Abstr. Rev. A. 68:107-117.

Di Marco, O. E., M. S. Aello, and D. G. Mendez. 1996. Energy expenditure of cattle grazing of pasture of low and high availability. Anim. Sci. 63:45-50.

Dougherty, C. T., N. W. Bradley, P. L. Cornelius, and L. M. Lauriault. 1989. Short-term fasts and the ingestive behaviour of grazing cattle. Grass Forage Sci. 44:295-302.

Flores, E. R., E. A. Laca, T. C. Griggs, and M. W. Demment. 1993 Sward height and vertical morphological differentiation determine cattle bite dimensions. Agron. J. 85:527-532.

Forbes, J. M. 2003. The multifactorial nature of food intake control. J. Anim. Sci. 81(E Suppl. 2):E139-E144.

Fortin, D. 2001. An adjustment of the extended contingency model of Farnsworth and Illius (1998). Funct. Ecol. 15:138-139.

Galli, J. R.. C. A. Cangiano, M. W. Demment, and E. A. Laca. 2006 Acoustic monitoring of chewing and intake of fresh and dry forages in steers. Anim. Feed Sci. Technol. 128:14-30.

Gentry, P. C., J. P. Willey, and R. J. Collier. 2003. Ghrelin, a growth hormone secretagogue, is expressed by bovine rumen. J. Anim. Sci. 81(Suppl. 1):123. (Abstr.)

Gibb, M. J., C. A. Huckle, R. Nuthall, and A. J. Rook. 1997. Effect of sward surface height on intake and grazing behaviour by lactating Holstein Friesian cows. Grass Forage Sci. 52:309-321.

Gil-Campos, M., C. M. Aguilera, R. Cañete, and A. Gil. 2006. Ghrelin: A hormone regulating food intake and energy homeostasis. Br. J. Nutr. 96:201-226.
Gregorini, P., J. Caldwell, W. Coblentz, P. Beck, and S. A. Gunter. 2006. Why conservational tillage? An animal perspective... Pages 255-259 in Proc. American Forage and Grassland Counc. Ann. Mtg., San Antonio, TX. Am. Forage Grassl. Counc., Elmhurst, IL.

Gregorini, P., M. Eirin, M. H. Wade, R. Refi, M. Ursino, O. Ansin, and S. A. Gunter. 2007b. The effects of a morning fasting on the evening grazing behavior and performance of strip-grazed beef heifers. Prof. Anim. Sci. 23:642-648.

Gregorini, P., S. A. Gunter, C. A. Masino, and P. Beck. 2007a. Effect of ruminal fill on short-term intake rate and grazing dynamics. Grass Forage Sci. 62:346-354.

Gregorini, P., S. A. Gunter, P. A. Beck, K. J. Soder, and S. Tamminga. 2008. Review: The interaction of diurnal grazing pattern, ruminal metabolism, nutrient supply and management in cattle. Prof. Anim. Sci. 24:308-318.

Griffiths, W. M., and I. J. Gordon. 2003. Sward structural resistance and biting effort in grazing ruminants. Anim. Res. 52:145-160.

Grovum, W. L. 1995. Mechanisms explaining the effect of short-term fatty acids on feed intake in ruminants, osmotic pressure, insulin and glucagons. Pages 137-197 in Ruminant Physiology: Digestion, Metabolism, Growth, Reproduction. W. V. Engelhardt, S. Leonhard-Marek, G. Breves, D. Giesescke, ed. Proc. 8th Int. Symp. Ruminant Physiol. Ferdinan Enke Verlag, Stuttgart, Germany.

Hayashida, T., K. Murakami, K. Mogi, M. Nishihara, M. Nakazato, M. S. Mondal, Y. Horii, M. Kojima, K. Kangawa, and N. Murakami. 2001. Ghrelin in domestic animals: Distribution in stomach and its possible role. Domest. Anim. Endocrinol. 21:17-24.

Hobbs, N. T., J. E. Gross, L. A. Shipley, D. E. Spalinger, and B. A. Wunder. 2003. Herbivore functional response in heterogeneous environments: A contest among models. Ecology 84:666-681.

Hodgson, J., D. A. Clark, and R. J. Mitchell. 1994. Foraging behaviour in grazing animals and its impact on plant communities. Pages 796-827 in Forage Quality, Evaluation, and Utilization. G. C. Fahey, ed. ASA-CSSA-SSSA, Madison, WI

Hosada, H., M. Kojima, and K. Kangawa. 2002. Ghrelin and intake regulation of food intake and energy balance. Mol. Interv. 2:494503.

Illius, A. W., and N. S. Jessop. 1996. Metabolic constraints on voluntary intake in ruminants. J. Anim. Sci. 74:3052-3062.

Itoh, F., T. Komatsu, S. Kushibiki, and K. Hodate. 2006. Effects of ghrelin injection on plasma concentrations of glucose, pancreatic hormones and cortisol in Holstein dairy cattle. Comp. Biochem. Physiol. 143:97-102.

Ivlev, V. S. 1961. Experimental Ecology of the Feeding of Fishes. Yale Univ. Press, New Haven, CT.

Kobelt, P., S. Helmling, A. Stengel, B. Wlotzka, V. Andresen, B. F. Klapp, B. Wiedenmann, S. Klussmann, and H. Mönnikes. 2006. Anti-ghrelin Spiegelmer NOX-B11 inhibits neurostimulatory and orexigenic effects of peripheral ghrelin in rats. Gut 55:788-792.

Kuehl, R. O. 1999. Design of Experiments: Statistical Principles of Research Design and Analysis. 2nd ed. Duxbury Press, Pacific Grove, CA.

Laca, E. A., L. A. Shipley, and E. D. Reid. 2001. Structural antiquality characteristics of range and pasture plants. J. Range Manage. 54:413-419.

Laca, E. A., and E. D. Ungar. 1992. Effects of sward height and bulk density in bite dimensions of cattle grazing homogeneous swards. Grass Forage Sci. 47:91-102.

Mendez, P., K. Traci, J. White, L. Badinga, J. Verstegen, G. A. Donovan, and L. F. Archvald. 2006. Effect of ghrelin in dry matter intake and energy metabolism in prepartum sheep: A preliminary study. Theriogenology 66:1961-1968.

Miura, H., N. Tsushiya, I. Sasaki, M. Kikuchi, M. Kojima, K. Kangawa, Y. Hasegawa, and Y. Ohnami. 2004. Changes in plasma ghrelin and hormone concentration in mature Holstein cows and threemonth-old calves. J. Anim. Sci. 82:1329-1333.

Nakazato, M., N. Murakami, Y. Date, M. Kojuma, H. Matsue, K. Kangawa, and S. Matsukura. 2001. A role for ghrelin in the control of feeding. Nature 409:194-198. 
Newman, J. A., P. D. Penning, A. J. Parsons, A. J. Harvey, and R. J. Orr. 1994. Fasting affects grazing behaviour and diet preference of grazing sheep. Anim. Behav. 47:185-193.

NRC. 2001. Nutrient Requirements of Dairy Cattle. 7th rev. ed. Natl. Acad. Press, Washington, DC.

Orr, R. J., K. L. Young, J. E. Cook, and R. A. Champion. 2005. Development of a micro-sward technique for determining intake characteristics of perennial ryegrass varieties. Euphytica 141:6573.

Patel, A. D., S. A. Stanley, K. G. Murphy, G. S. Frost, J. V. Gardiner, A. S. Kent, N. E. White, M. A. Ghatei, and S. R. Bloom. 2006. Ghrelin stimulates insulin-induced glucose uptake in adipocytes. Regul. Pept. 134:17-22.

Patterson, D. M., D. A. McGilloway, A. Cushnahan, C. S. Mayne, and A. S. Laidaw. 1998. Effect of duration of fasting period on short term intake rates of lactating dairy cows. Anim. Sci. 66:299305.

Perez-Barbería, F. J., and I. J. F. Gordon. 1998. Factors affecting food comminution during chewing in ruminants: A review. Biol. J. Linn. Soc. Lond. 63:233-256.

Roche, J. R., A. J. Sheahan, L. M. Chagas, and D. P. Berry. 2007. Concentrate supplementation reduces postprandial plasma ghrelin in grazing dairy cows: A possible neuroendocrine basis for reduced pasture intake in supplemented cows. J. Dairy Sci. 90:13541363.

Roche, J. R., A. J. Sheahan, L. M. Chagas, and R. C. Boston. 2008. Short communication: Change in plasma ghrelin in dairy cows following an intravenous glucose challenge. J. Dairy Sci. 91:10051010.

Rutter, S. M. 2000. Graze: A program to analyze recordings of the jaw movements of ruminants. Behav. Res. Methods Instrum. Comput. 32:86-92.

Rutter, S. M., R. A. Champion, and P. D. Penning. 1997. An automatic system to record foraging behaviour in free ranging ruminant. Appl. Anim. Behav. Sci. 54:185-195.

Sugino, T., Y. Hasegawa, Y. Kurose, M. Kojima, K. Kangawa and Y. Terashima. 2004. Effects of ghrelin on food intake and neuroendocrine function in sheep. Anim. Reprod. Sci. 82-83:183194.

Sugino, T., J. Yamaura, M. Yamagishi, Y. Kurose, M. Kojima, K. Kangawa, Y. Hasegawa, and Y. Terashima. 2003. Involvement of cholinergic neurons in the regulation of the secretory response to feeding in sheep. Biochem. Biophys. Res. Commun. 304:308 312 .

Takahashi, H., Y. Kurose, S. Kobayashi, T. Sugino, M. Kojima, K. Kangawa, Y. Hasegawa, and Y. Terashima. 2006. Ghrelin enhances glucose-induced insulin secretion in scheduled meal-fed sheep. J. Endocrinol. 189:67-75.

Tang-Christensen, M., N. Vrang, and S. Ortman. 2004. Central administration of ghrelin and agouti-related protein (83-132) increases food intake and decreases spontaneous locomotor activity in rats. Endocrinology 145:4645-4652.

Taweel, H. Z., B. M. Tas, J. Dijkstra, and S. Tamminga. 2005. Intake regulation and grazing behavior of dairy cows under continuous stocking. J. Dairy Sci. 87:3417-3427.

Thiago, L. R. L. de S. 1988. Voluntary intake of forages by ruminants: Factors related to eating behaviour and rumen fill. PhD Diss. University of Reading, Reading, UK.
Thomson, B. C., G. J. Cruickshank, D. P. Poppi, and A. R. Sykes. 1985. Diurnal patterns of rumen fill in grazing sheep. Proc. N.Z. Soc. Anim. Prod. 45:117-120.

Trinder, P. 1959. Determination of blood glucose using 4-aminophenazone. J. Clin. Pathol. 22:246.

Ungar, E. D. 1996. Ingestive behavior. Pages $185-218$ in The Ecology and Management of Grassland Systems. J. Hodgson and A. W. Illius, ed. CAB International, Wallingford, UK.

Ungar, E. D., and I. Noy-Meir. 2001. Herbage intake in relation to the availability and sward structure: Grazing process and optimal foraging. J. Appl. Ecol. 25:1045-1062.

Vickers, Z. 1977. What sounds good for lunch? Cereal Foods World. $22: 246-247$.

Vincent, J. F. V. 1983. The influence of water content on the stiffness and fracture properties of grass leaves. Grass Forage Sci. 38:107114.

Wade, M. H. 1991. Factors affecting the availability of vegetative Lolium perenne to grazing dairy cows with special reference to sward characteristics, stocking rate and grazing method. $\mathrm{PhD}$ Diss., Université de Rennes, Rennes, France.

Wade, M. H., and P. de F. Carvalho. 2000. Defoliation patterns and herbage intake in grazed pastures. Pages 233-248 in Ecophysiology of Grasslands and the Ecology of Grazing. P. C. de F. Carvalho, C. Nabinger, G. Lemaire, J. Hodgson, and A. de Moraes, ed. CAB International, Oxford, UK.

Wade, M. H., M. Eirin, and P. Gregorini. 2006. The effect of fasting on the feeding station behavior of grazing beef heifers . J. Anim. Sci. 84(Suppl. 2):51. (Abstr.)

Wade, M. H., J. L. Peyraud, G. Lemaire, and E. A. Comeron. 1989. The dynamics of daily area and depth of grazing and herbage intake of cows in a five day paddock system. Pages 1111-1112 in Proc. 16th International Grassland Congress, Nice, France. The French Grassland Society, Nice.

Wertz-Lutz, A. E., J. A. Daniel, J. A. Clapper, A. Trenkle, and D. C. Beitz. 2008. Prolonged, moderate nutrient restriction in beef cattle results in persistently elevated circulating ghrelin concentrations. J. Anim. Sci. 86:564-575.

Wertz-Lutz, A. E., T. J. Knight, R. H. Pritchard, J. A. Daniel, J. A. Clapper, A. J. Smart, A. Trenkle, and D. C. Beitz. 2006. Circulating ghrelin concentrations fluctuate relative to nutritional status and influence feeding behavior in cattle. J. Anim. Sci. 84:3285-3300.

Weston, R. H. 1996. Some aspects of constraint to forage consumption by ruminants. Aust. J. Agric. Res. 47:175-198.

Woods, S., E. Lotter, L. Mc Kay, and D. J. Porte. 1979. Chronic intracerebroventricular infusion of insulin reduce food intake and body weight in baboons. Nature 282:503-505.

Wren, A. M., L. J. Seal, M. A. Cohen, A. E. Brynes, G. S. Frost, K. G. Murphy, W. S. Dhillo, M. A. Ghatei, and S. R. Bloom. 2000 Ghrelin enhances appetite and increases food intake in humans. J. Clin. Endocrinol. Metab. 86:5992-5995.

Wright, W., and A. W. Illius. 1995. A comparative study of the fracture properties of five grasses. Funct. Ecol. 9:269-278. 